\title{
COMBUSTION OF KEROSENE SPRAYS
}

\author{
Abd El-Samed A. K., Gad, H. M., Habik, S. E., and Farag T. M.
}

\begin{abstract}
The combustion of the kerosene sprays inside a swirl type combustor is studied. To decrease the exhaust emissions such as $\mathrm{NOx}, \mathrm{NO}$ and $\mathrm{SO}_{2}$, Natural Gas (NG) or Liquefied Petroleum Gas (LPG) fuels are added to the combustion air with different ratios. The effects of different percentages of NG $(10,20,30$ and $40 \%)$, different percentages of LPG $(1,2,3$ and $4 \%$ ), and thermal load $(70,100$ and $130 \mathrm{~kW})$ on the flame characteristics were investigated. Also, a comparison between addition of NG and LPG was carried out. During the experimental study, the air to fuel mass ratio and air swirl number are kept constants at 30 and 0.5 , respectively. The experimental results show that, as the NG percentage increases from 10 to $40 \%$, the flame lengths and the flame temperatures were decreased, so that, $\mathrm{NO}_{\mathrm{X}}, \mathrm{NO}, \mathrm{CO}_{2}$ and $\mathrm{SO}_{2}$ concentrations were decreased, while $\mathrm{CO}$ and $\mathrm{O}_{2}$ concentrations were increased. Also, as the LPG percentage increases, the flame lengths and the flame temperatures were decreased, so that, $\mathrm{NO}_{\mathrm{x}}$ and $\mathrm{NO}, \mathrm{CO}_{2}$ and $\mathrm{SO}_{2}$ concentrations were decreased, while $\mathrm{CO}$ and $\mathrm{O}_{2}$ concentrations were decreased.

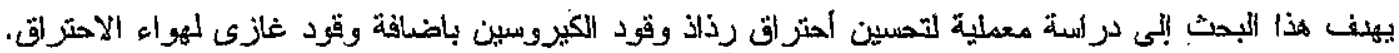

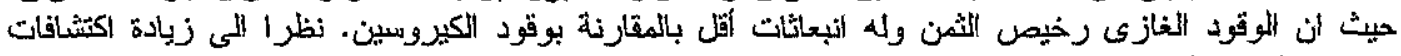

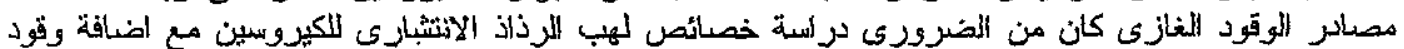

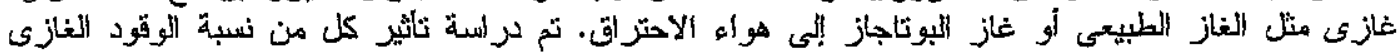

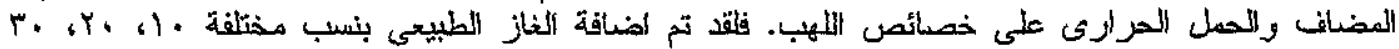

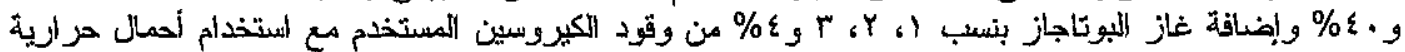

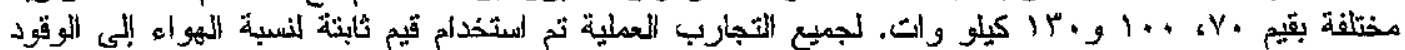

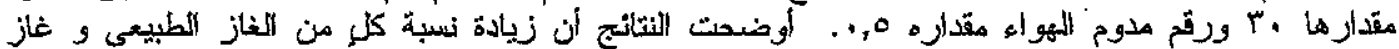

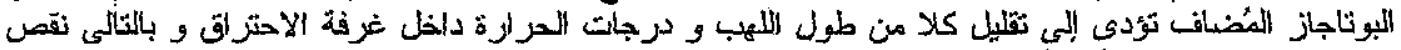

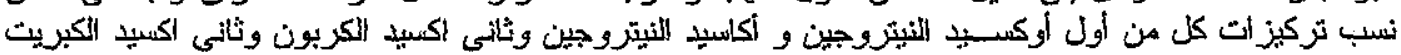
وزيادة نسبب تركيز ات كل من أول أكسيد الكربون و الاكسجين.
\end{abstract}

Keywords: Gas Turbine, Spray Combustion, Emissions, Swirling.

\section{INTRODUCTION}

The fuel burning represents the main source of energy in the present time. The role of such source of energy somewhat decreased after the discovery of the nuclear energy and exploitation of solar energy. Aiso, the application of the fuel in petrochemical industries is increasing and the economical use of the fuel becomes an important parameter. However, several years must pass before fuel losses its leading position.

The exhaust combustion emissions have harmful effects on the human health, soil and plants [14]. So that, many researchers studied various techniques for reducing the combustion emissions especially NO and $N O_{X}$ emissions $[2,5,11,12,13,18]$. The gaseous fuel additive to the combustion processes was considered as one of the most effective method for reducing $\mathrm{NO}_{\mathrm{x}}$ emissions. This is because it can assist in the production of the radical species necessary for reducing not only $\mathrm{NO}$, but also $\mathrm{NO}_{2}, \mathrm{~N}_{2} \mathrm{O}$, and may also lead to increase the burning velocity $[5,18]$.

Most experimental studies were mainly concerned with the flame characteristics for Kerosene fuel only $[1,6,8,10]$ or gaseous fuel only $[5,7,11,13]$. It can be seen that, the amount of information is relatively incomplete for combustion of dual fuel (Kerosene and NG). Therefore, in the present work, the flame characteristics of Kerosene fuel were studied when adding of NG and LPG to the combustion air by different percentages.

In the flame characteristic studies, temperature distributions in the axial and radial directions of the combustor were measured. In addition, the flame length and the exhaust species concentration at the end of the exhaust pipe were also measured. Temperature distributions were used to draw temperature maps. The flame length and different species concentration curves were drawn under different operating conditions. In order to study the above parameters, a test rig described below was constructed.

\section{EXPERIMENTAL TEST RIG}

The present experimental work is divided into two parts:

1- In the first part, NG fuel is added to the combustion air (as a mass percentage of $\mathrm{NG}$ to Kerosene fuel such as 10, 20, 30 and $40 \%$ ). The 
flame characteristics at these percentages were compared with similar conditions but without additives. The air to fuel mass ratio of 30 and the air swirl number of 0.5 were kept constants during all operating conditions for input thermal loads of 70,100 and $130 \mathrm{~kW}$.

2- In the second part, LPG fuel was added to the combustion air (as a mass percentage of LPG to Kerosene fuel such as $1,2,3$ and $4 \%$ ). The flame characteristics at these percentages were also compared with similar conditions, but without additives and with those of the first part.

The schematic drawing of the test rig is shown in Fig. 1. A water cooled swirl type combustor of inner diameter $25 \mathrm{~cm}$ and $100 \mathrm{~cm}$ length was constructed to burn Kerosene fuel with air. The Kerosene fuel flow from the fuel tank and enters the combustor through a pressure swirl atomizer. The gaseous fuel was mixed with the combustion air of Kerosene fuel in the air duct at a distance of $2 \mathrm{~m}$ upstream the inlet of the combustor to insure good mixing with combustion air. The gaseous fuel flows from a pressurized gas cylinder, filled with NG at about 200 bar and with LPG at about 3 bar. A pressure regulator. was fitted on the gas cylinder to adjust the output gas pressure and consequently the issued mass flow rate. The gaseous fuels flow rates were measured and calibrated at different pressures using a rotameter device. The chemical compositions of NG and LPG are given in Tables 1 and 2, respectively.

Table 1 Chemical composition of the NG (Natural Gas Vehicles Co. 2003)

\begin{tabular}{|l|c|c|c|}
\hline \multicolumn{1}{|c|}{ Substance } & $\begin{array}{c}\text { Chemical } \\
\text { Formula }\end{array}$ & $\begin{array}{c}\% \text { by } \\
\text { Volume }\end{array}$ & $\begin{array}{c}\text { \% by } \\
\text { Mass }\end{array}$ \\
\hline Methane & $\mathrm{CH}_{4}$ & 91.43 & 83.62 \\
\hline Ethane & $\mathrm{C}_{2} \mathrm{H}_{6}$ & 4.10 & 7.03 \\
\hline Propane & $\mathrm{C}_{3} \mathrm{H}_{8}$ & 0.99 & 2.49 \\
\hline Butanes & $\mathrm{C}_{4} \mathrm{H}_{10}$ & 0.33 & 1.09 \\
\hline Pentanes & $\mathrm{C}_{5} \mathrm{H}_{12}$ & 0.10 & 0.41 \\
\hline Nitrogen & $\mathrm{N}_{2}$ & 2.53 & 4.05 \\
\hline Helium & $\mathrm{He}_{1}$ & - & - \\
\hline Carbon Dioxide & $\mathrm{CO}_{2}$ & 0.52 & 1.31 \\
\hline
\end{tabular}

Table 2 Chemical composition of LPG (Egypt Gas Co. 2003)

\begin{tabular}{|l|c|c|c|}
\hline Substance & $\begin{array}{c}\text { Chemical } \\
\text { Formula }\end{array}$ & $\begin{array}{c}\% \text { by } \\
\text { Volume }\end{array}$ & \% by Mass \\
\hline Butane & $\mathrm{C}_{4} \mathrm{H}_{10}$ & 87.1 & 90.83 \\
\hline Propane & $\mathrm{C}_{3} \mathrm{H}_{8}$ & 7.2 & 5.70 \\
\hline Propylene & $\mathrm{C}_{3} \mathrm{H}_{6}$ & 4.2 & 3.17 \\
\hline Methane & $\mathrm{CH}_{4}$ & 0.1 & 0.03 \\
\hline Ethane & $\mathrm{C}_{2} \mathrm{H}_{6}$ & 0.5 & 0.27 \\
\hline
\end{tabular}
1-fuel gear pump
7-fucl by pass valve
2-main fuel value
3-glass tube fuel indicator 4-Karosent tank
5.fillter
6-fuel by-pass valve
8 -gus bomb
9-pressura regulator
10-gzas inlat value
It-U-tube water manometer 12-venturi meler
13-gas outlet valve
14-mercury thermometer for couling water outlet
15-cooling water outlet 16-combustor 17-chimney 18-futl pressure gauge
19-fuel fine tilter
20-fuel values
21-tombustion air blower 22-combustion air control valye 23-oriffe meter 24-U-tube water masomatur
25 - gastous additives nozkles 26-combustion air swirler
23-pressure swirl atomizur
28-cooling water jacket 29-cooling water inlet 30 -exhatst entistions point

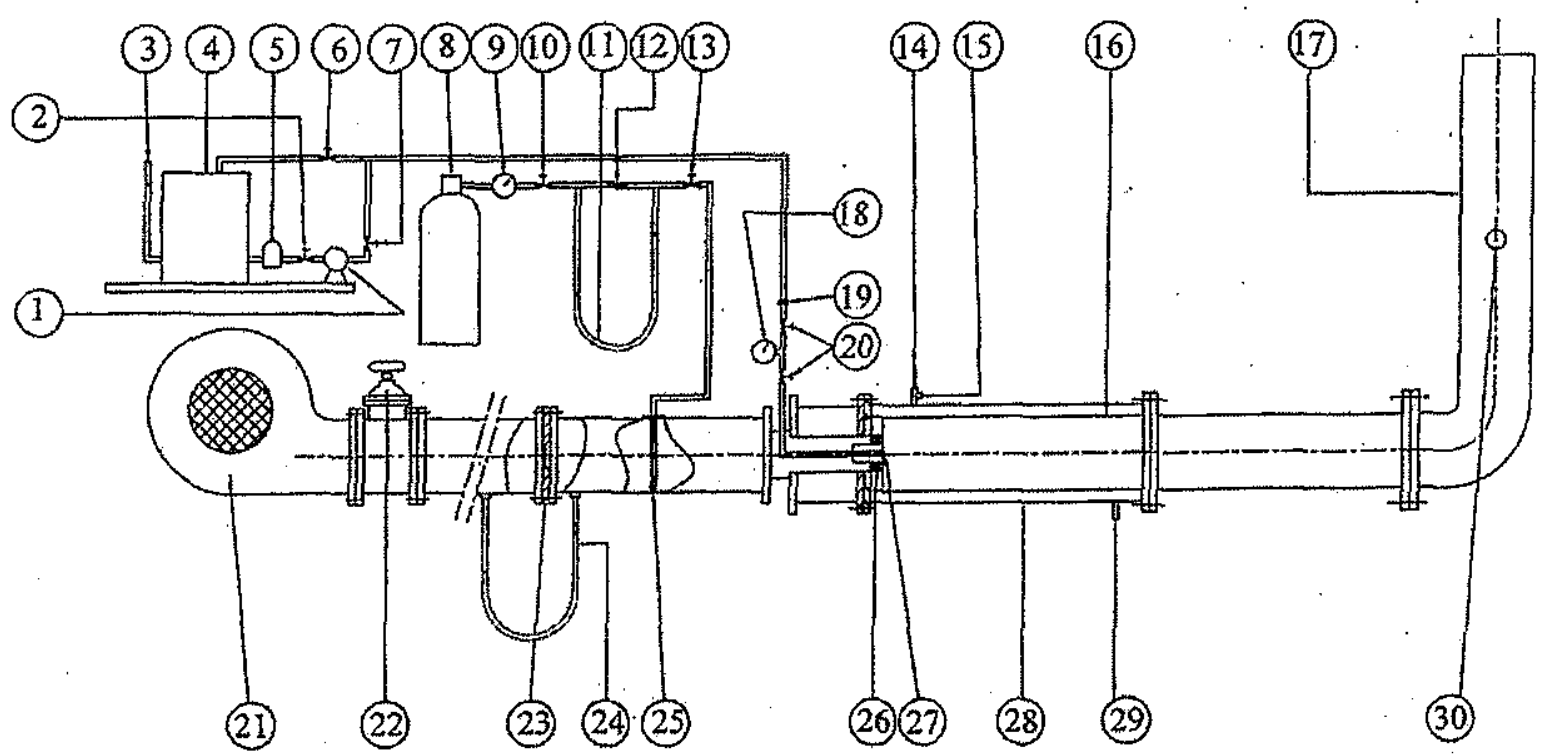

Fig. 1. Schematic diagram of the experimental test rig. 
The pressure swirl atomizer that located centrally in the combustion air swirler was designed to ensure that the Kerosene fuel was issued with a swirl motion through a swirl (spin) chamber. A $5 \mathrm{~kW}$ blower was used to obtain the combustion air. The air flow rate was measured by means of a calibrated orifice meter and U-tube manometer. The gaseous fuel enters the combustion air duct through the gas distributor. This distributor consists of a vertical pipe of $12 \mathrm{~mm}$ diameter and $150 \mathrm{~mm}$ length, closed from one end, while the other end is connected through the gaseous hoses to the gaseous cylinder. The combustor was equipped by 17 taping holes for the required measurements. The temperatures were measured along a half of the combustor tube using a bare wire thermocouple, type $\mathrm{R}$ ( $\mathrm{Pt}$ and $\mathrm{Pt} \& 13 \% \mathrm{Rh}$ materiais). A photograph of the experimental test rig is shown in Fig. 2. The burner consists of a pipe of $100 \mathrm{~mm}$ inner diameter. The air swirler is fitted coaxially inside the burner tube. The pressure swirl atomizer is also fitted co-axially with the air swirler at the combustor entrance, as shown in Fig. 3. The shape and dimensions of the pressure swirl atomizer and the air swirler are shown in Figs. 4 and 5 respectively.

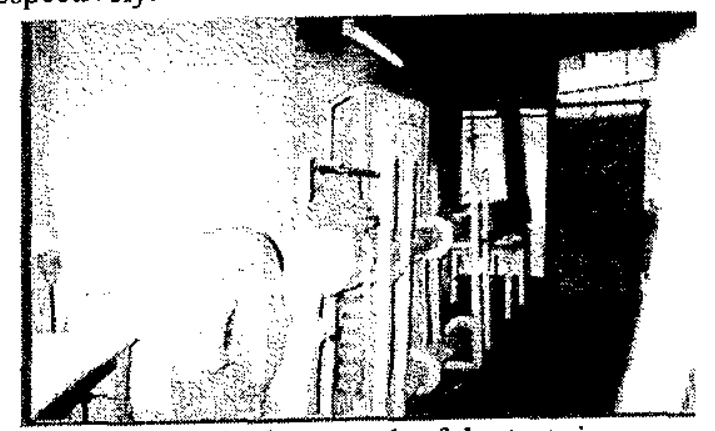

Fig. 2. A photograph of the test rig

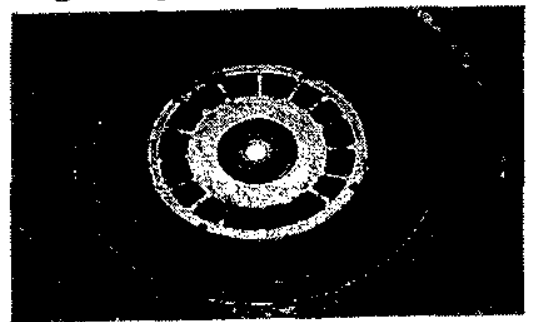

Fig. 3. A photograph of the burner arrangement

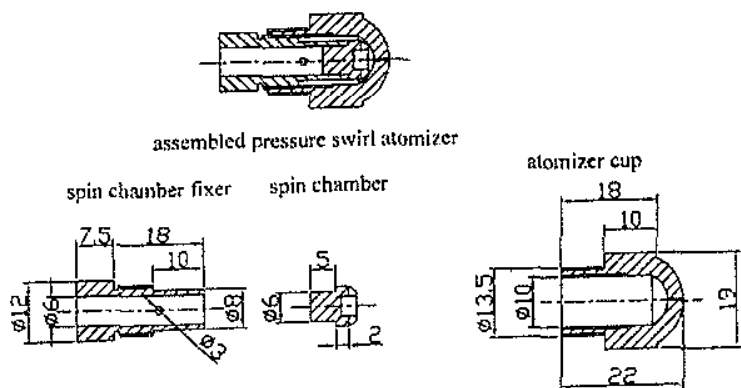

Fig. 4. Assembly and construction of the pressure swirl atomizer

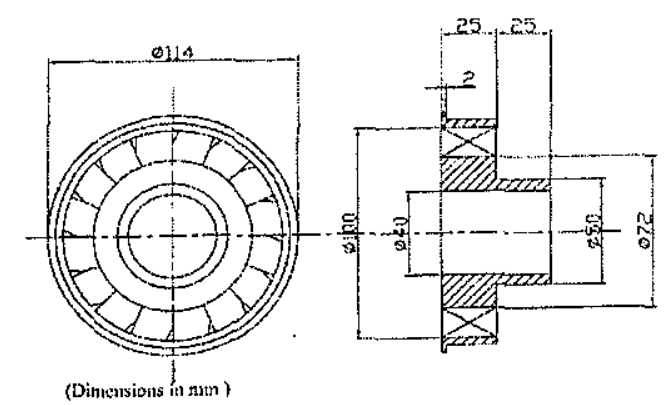

Fig. 5. Dimensions and detailed construction of the combustion air swirler

The NG fuel was added at different mass percentages to the Kerosene fuel such as $10,20,30$ and $40 \%$, while the LPG fuel was added at different mass percentages to the Kerosene fuel such as $1,2,3$ and $4 \%$. The Kerosene fuel mass flow rate is calculated to ensure that, the input thermal load with the additions is kept constant. Three input thermal loads of 70,100 and $130 \mathrm{~kW}$ are used. The air swirl number and air to fuel mass ratio are kept constants at 0.50 and 30 , respectively.

The experimental study of combustion characteristics were carried out in two ways. The first one was obtained by adding NG fuel to the combustion air of Kerosene fuel by different percentages at different input thermal loads. The second one was achieved by replacing the NG fuel by LPG. The temperature distributions, visible flame lengths and exhaust species concentration were measured.

The temperatures were measured radially and at different axial distance from the measuring holes. From the radial and the axial temperature distribution maps could be drawn for given operating conditions with the aid of MS Excel program for these purposes. The temperatures map is described by six temperature regions; each region has a range of temperatures described by a certain color. The higher temperatures region (i.e. from 1400 to $1600 \mathrm{~K}$ ) is described by the black color. When the color is more blackness, this indicates that the temperature range is high.

\section{EXPERIMENTAL RESULTS DISCUSSION}

\subsection{Temperature Distributions \\ 3.1.1 Effect of NG addition}

The temperature maps for different operating conditions are shown in Figs.6-10 assuming axisymmetric measurements along the combustor. Figure 6 shows the effect of different percentages of $N G$ fuel at constants values of thermal load, air swirl number and air to fuel mass ratio on temperature distribution maps. The figure shows that, the different percentages of NG fuel enter the combustion zone were burned rapidly nearer to the air swirler. The heat released from the combustion of 
$N G$ fuel increases the rate of evaporation of Kerosene fuel and this leads to increase in the mixing rate. That increases the chemical reaction rate or leading to improve the combustion process and consequently the flame size decreases causing the high temperature regions shift upstream.
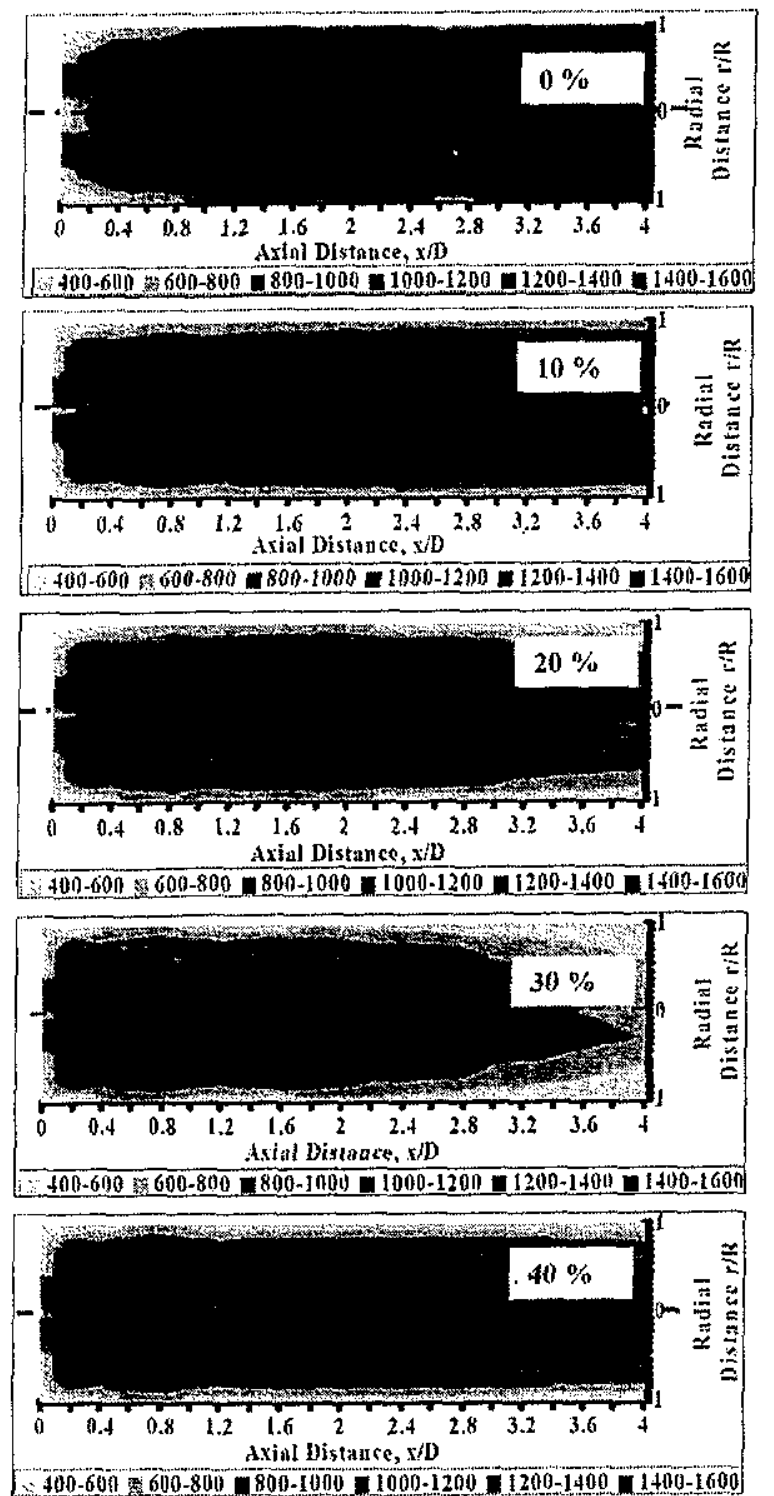

Fig. 6 Effect of NG percentage on temperatures maps in $\mathrm{K}$ at input thermal load of $130 \mathrm{~kW}$

\subsubsection{Effect of LPG addition}

The effect of different percentages of LPG fuel at constants values of thermal load, air swirl number and air to fuel mass ratio on temperature distribution maps is shown in Fig. 7. The figure shows that, the heat released from the combustion of $\mathrm{LPG}$ fuel increases the rate of evaporation of Kerosene fuel and this leads to increase in the mixing rate. That increases the chemical reaction rate or leading to improve the combustion process and consequently the flame size decreases causing the high temperature regions shifted down stream, the same effect as the addition of the NG as described before.
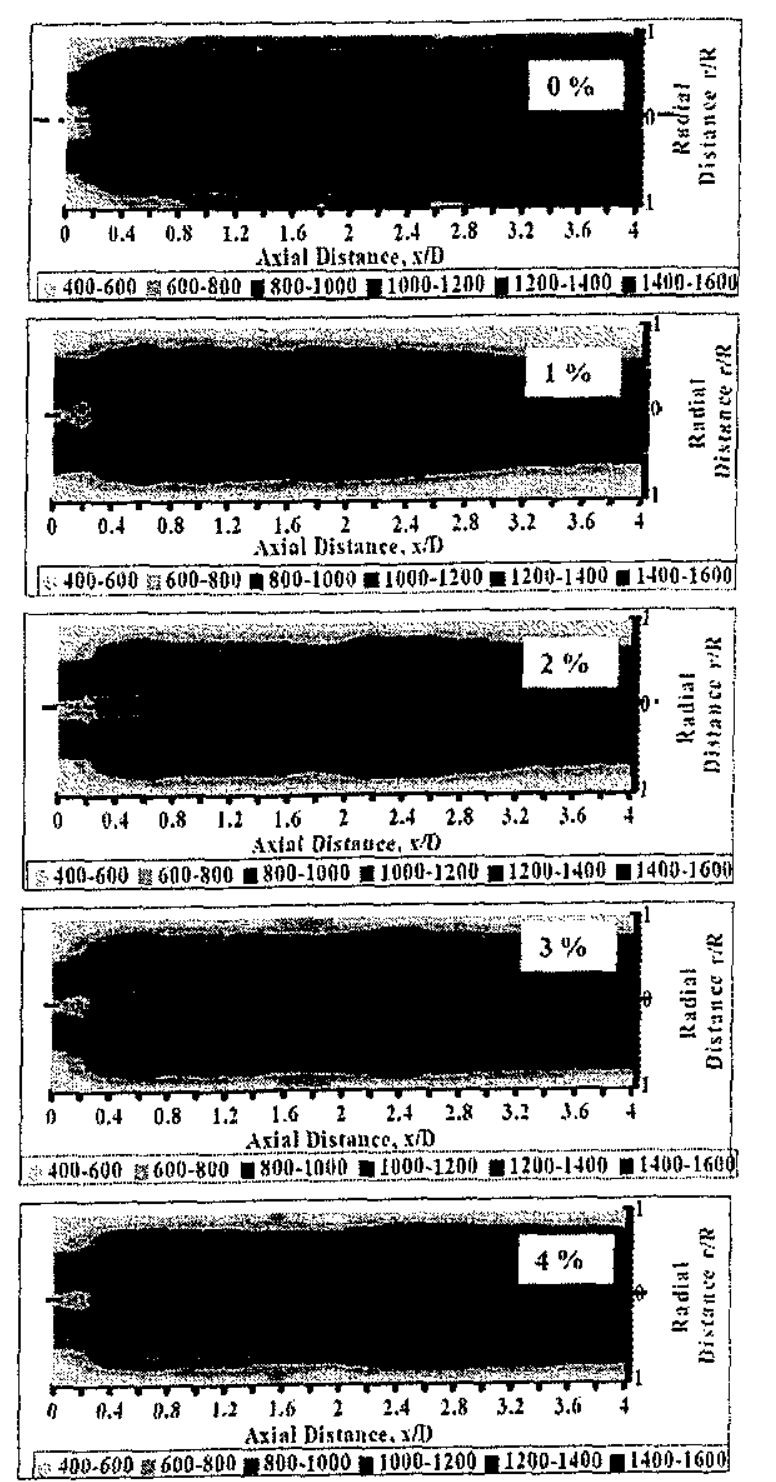

Fig. 7. Effect of LPG percentage on temperatures maps in $\mathrm{K}$ at input thermal load of $130 \mathrm{~kW}$

\subsubsection{Effect of input thermal load}

The effects of the input thermal load on the temperature maps when adding NG and LPG fuels to the combustion air are shown in Figs. 8 and 9 respectively. From these figures, it can be noticed that increasing the input thermal load leads to increase in the fuel momentum as a result of increasing the fuel mass flow rate and the fuel pressure. Furthermore, the high temperature regions shifted downstream, and increased in size while the flame length is increased due to the increase of the fuel momentum. 
Abd El-Samed A. K., Gad, H. M., Habik, S. E., and Farag T. M., "Combustion of Kerosene Sprays".

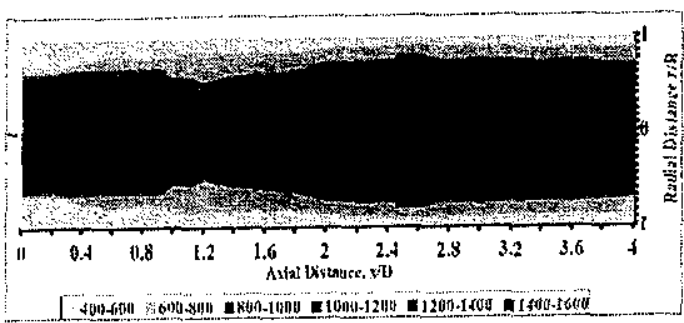

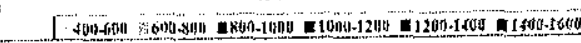

Thomal loxul $=70 \mathrm{~kW}$

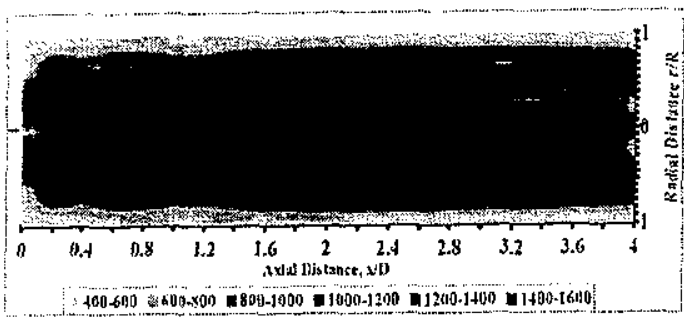

Thennal lsad $=100 \mathrm{~kW}$

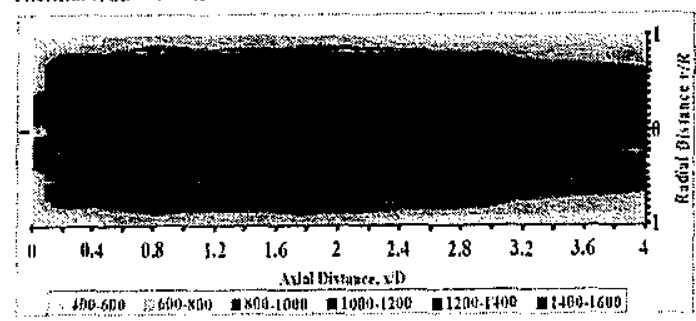

|'beunt ket $\div 130 \mathrm{~kW}$

Fig. 8. Effect of the input thermal load on the temperatures maps in $\mathrm{K}$ at the NG percentage of $20 \%$
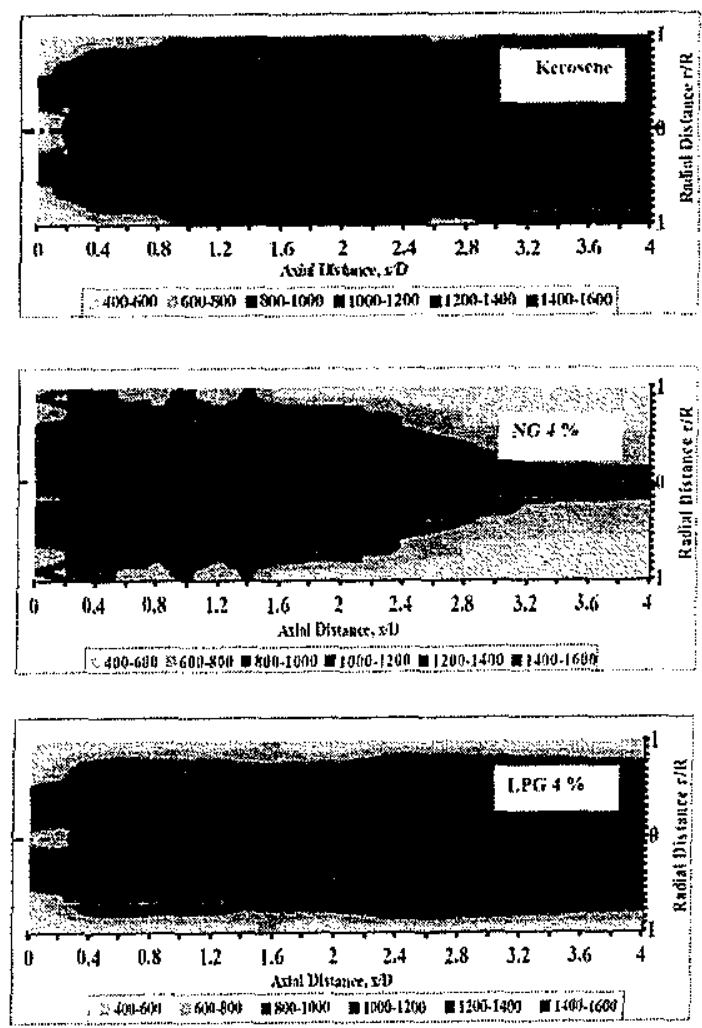

Fig. 9. Effect of the input thermal load on the temperatures maps in $\mathrm{K}$ at LPG percentage of $3 \%$

\subsubsection{Comparison between NG and LPG additions}

A comparison between the NG and LPG fuels addition when be added by the same percentage is shown in Fig. 10. The figure shows that, for the NG fuel, the high temperature region is found between the axial to diameter ratios of 1.0 and 1.2. But this region is found between 1.0 and 2.2 for LPG. The high temperature region size is greater for LPG than that for NG and the flame size is greater for LPG than for $N G$ (for NG, it is shorter in length but wider in diameter). For $\mathrm{NG}$ the temperatures are lower than that for LPG. This is because the heating value of LPG is greater than that of NG. Therefore, the heat released from combustion of $L P G$ is greater than that of the NG.

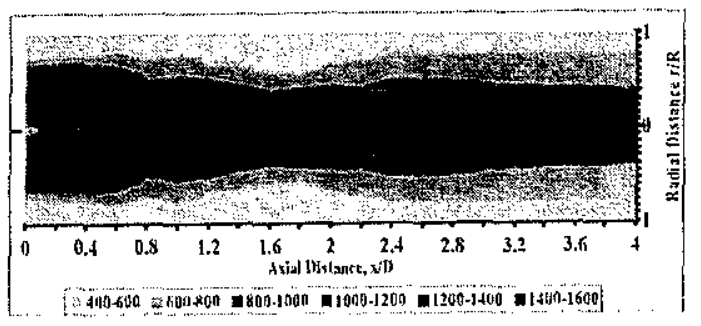

ThesIII lond $=79 \mathrm{~kW}$

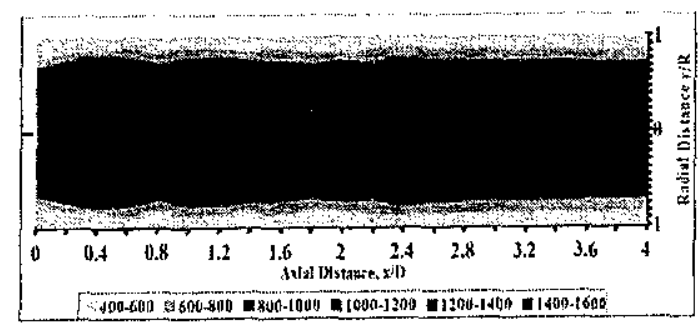

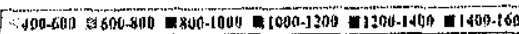

Themal lond - 1(4) $\mathrm{kW}$

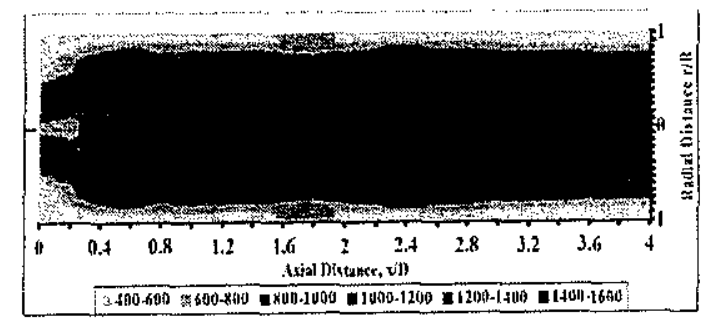

Themal todd $\because 130 \mathrm{~kW}$

Fig. 10. Temperatures maps in $\mathrm{K}$ for the same percentage of NG and $\mathrm{LPG}$ of $4 \%$ at input thermal load of $130 \mathrm{~kW}$

\subsection{Effect of Adding Different Percentages of NG and LPG on:}

a) The visible flame length

The effects of adding different percentages of $\mathrm{NG}$ and LPG fuels to the combustion air of Kerosene fuel on the visible flame length are shown in Figs. 11 and 12 , respectively. It is shown that, when adding the NG, the flame length remarkably decreased as shown in Fig. 11. But when adding the LPG, the flame length slightly decreased as shown in Fig. 12. 


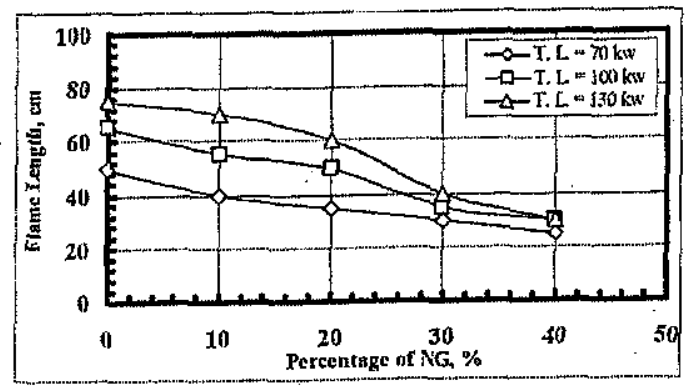

Fig. 11. Effect of adding NG fuel with different percentages on flame length

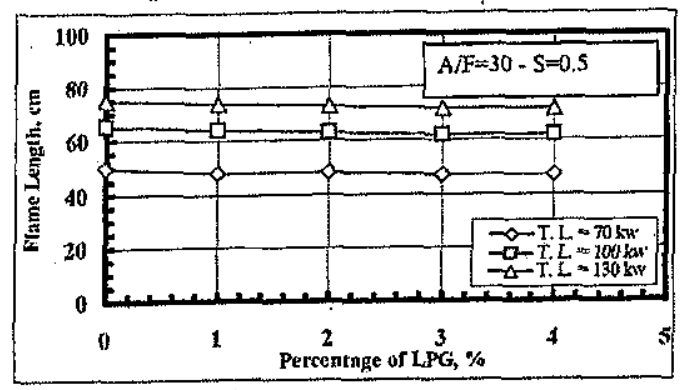

Fig. 12. Effect of adding LPG fuel with different percentages on flame length

\section{b) The exhaust species concentration}

It is important to study and discuss the experimental results reported by measuring some of exhaust species such as $\mathrm{NO}, \mathrm{NOx}, \mathrm{CO}, \mathrm{CO}_{2}, \mathrm{O}_{2}$ and $\mathrm{SO}_{2}$ concentrations at different operating conditions. The above species concentrations were measured using digital gas analyzer (Model Testo 350). The measuring port is at the middle of the chimney to avoid the effect of the atmospheric air on the concentrations of exhaust species and to be sure that the exhaust flow is steady. The exhaust concentrations were measured radially in the port cross-section and the mean value was obtained. The effects of the different operating conditions, such as NG and LPG percentages and input thermal load on the species concentration have been investigated.

The effects of NG and LPG percentages on the species concentration are shown in Figs. 13 and 14, respectively. Figure 13 shows that by increasing NG percentage, the average exhaust temperature decreased accompanied with a decrease of $\mathrm{NO}, \mathrm{NO}_{\mathrm{X}}$, $\mathrm{CO}_{2}$ and $\mathrm{SO}_{2}$ concentrations, but an increase of $\mathrm{CO}$ and $\mathrm{O}_{2}$ concentrations $[2,11,12,18]$.

Increasing the NG percentage from 0 to $40 \%$ keeping air swirl number of 0.50 , air to fuel mass ratio of 30 and input thermal load of $100 \mathrm{~kW}$ constant- it was noticed that $\mathrm{NO}, \mathrm{NO}_{\mathrm{x}}, \mathrm{CO}_{2}$ and $\mathrm{SO}_{2}$ concentrations decreased by about 50,46,30 and $28 \%$, respectively. While $\mathrm{CO}$ and $\mathrm{O}_{2}$ concentrations increased by about 106 and $40 \%$, respectively.

Figure 14 shows the effect of LPG fuel percentage on the exhaust species concentrations. Increase of LPG percentage leads to a decrease of $\mathrm{NO}, \mathrm{NO}_{\mathrm{X}}, \mathrm{CO}_{2}$ and
$\mathrm{SO}_{2}$ concentrations, but it leads to an increase of $\mathrm{CO}$ and $\mathrm{O}_{2}$ concentrations. It is shown that, increasing LPG percentage from 0 to $4 \%$ at input thermal load of $100 \mathrm{~kW}$-keeping the air swirl number of 0.5 and air to fuel mass ratio of 30 constant- leads to a decrease of $\mathrm{NO}, \mathrm{NO}_{\mathrm{X}}, \mathrm{CO}_{2}$ and $\mathrm{SO}_{2}$ concentrations by about $41,38,33$ and $25 \%$, respectively, but an increase of $\mathrm{CO}$ and $\mathrm{O}_{2}$ concentrations by about 132 and $27 \%$, respectively.

\subsection{Effect of Changing Input Thermal Load and NG/LPG Percentages on:}

a) The exhaust species concentrations

The effects of changing the input thermal load on the species concentration with the addition of NG and LPG fuels to the combustion air are shown in Figs.15 and 16 respectively. Figure 15 shows that, adding NG and increasing the input thermal load from 70 to $130 \mathrm{~kW}$ led to an increase of $\mathrm{NO}, \mathrm{NO}_{\mathrm{x}}, \mathrm{CO}_{2}$ and $\mathrm{SO}_{2}$ concentrations but a decrease of $\mathrm{CO}$ and $\mathrm{O}_{2}$ concentrations. At constants air swirl number of 0.5 , air to fuel mass ratio of 30 and at NG percentage of $20 \%$, by increasing the input thermal load from 70 to $130 \mathrm{~kW}$ it was noticed that $\mathrm{NO}, \mathrm{NO}_{\mathrm{X}}, \mathrm{CO}_{2}$ and $\mathrm{SO}_{2}$ concentrations increased by about 64, 67, 15 and $26 \%$, respectively. While $\mathrm{CO}$ and $\mathrm{O}_{2}$ concentration decreased by about 23 and $11 \%$ respectively. At air swirl number of 0.5 , air to fuel mass ratio of 30 and NG percentage $40 \%$ by increasing the input thermal load from 70 to $130 \mathrm{~kW}$ it was noticed that NO, $\mathrm{NO}_{\mathrm{X}}, \mathrm{CO}_{2}$ and $\mathrm{SO}_{2}$ concentrations increased by about $71,67,20$ and $22 \%$, respectively. While $\mathrm{CO}$ and $\mathrm{O}_{2}$ concentrations decreased by about 22 and $16 \%$, respectively.

Figure 16 shows the effects of changing the input thermal load on species concentrations with the addition of LPG fuel to the combustion air. By increasing the input thermal load, the combustion flame temperatures increased accompanied with an increase of $\mathrm{NO}, \mathrm{NO}_{\mathrm{X}}, \mathrm{CO}_{2}$ and $\mathrm{SO}_{2}$ concentrations, but a decrease of $\mathrm{CO}$ and $\mathrm{O}_{2}$ concentrations. At $L P G$ percentage of $2 \%$, air swirl number of 0.5 and air to fuel mass ratio of 30 , by increasing the input thermal load from 70 to $130 \mathrm{~kW}$ it was noticed that NO, $\mathrm{NO}_{\mathrm{x}}, \mathrm{CO}_{2}$ and $\mathrm{SO}_{2}$ concentrations were increased by about $50,44,13$ and $25 \%$, respectively while $\mathrm{CO}$ and $\mathrm{O}_{2}$ concentrations decreased by about 12.5 and $15.2 \%$, respectively. At LPG percentage of $4 \%$, air swirl number of 0.5 and air to fuel mass ratio of 30 , by increasing the input thermal load from 70 to 130 $\mathrm{kW}$ it was noticed that $\mathrm{NO}, \mathrm{NO}_{\mathrm{X}}, \mathrm{CO}_{2}$ and $\mathrm{SO}_{2}$ concentrations were increased by about $60,42,20$ and $16 \%$, respectively, while $\mathrm{CO}$ and $\mathrm{O}_{2}$ concentrations decreased by about 11 and 18 , respectively. 

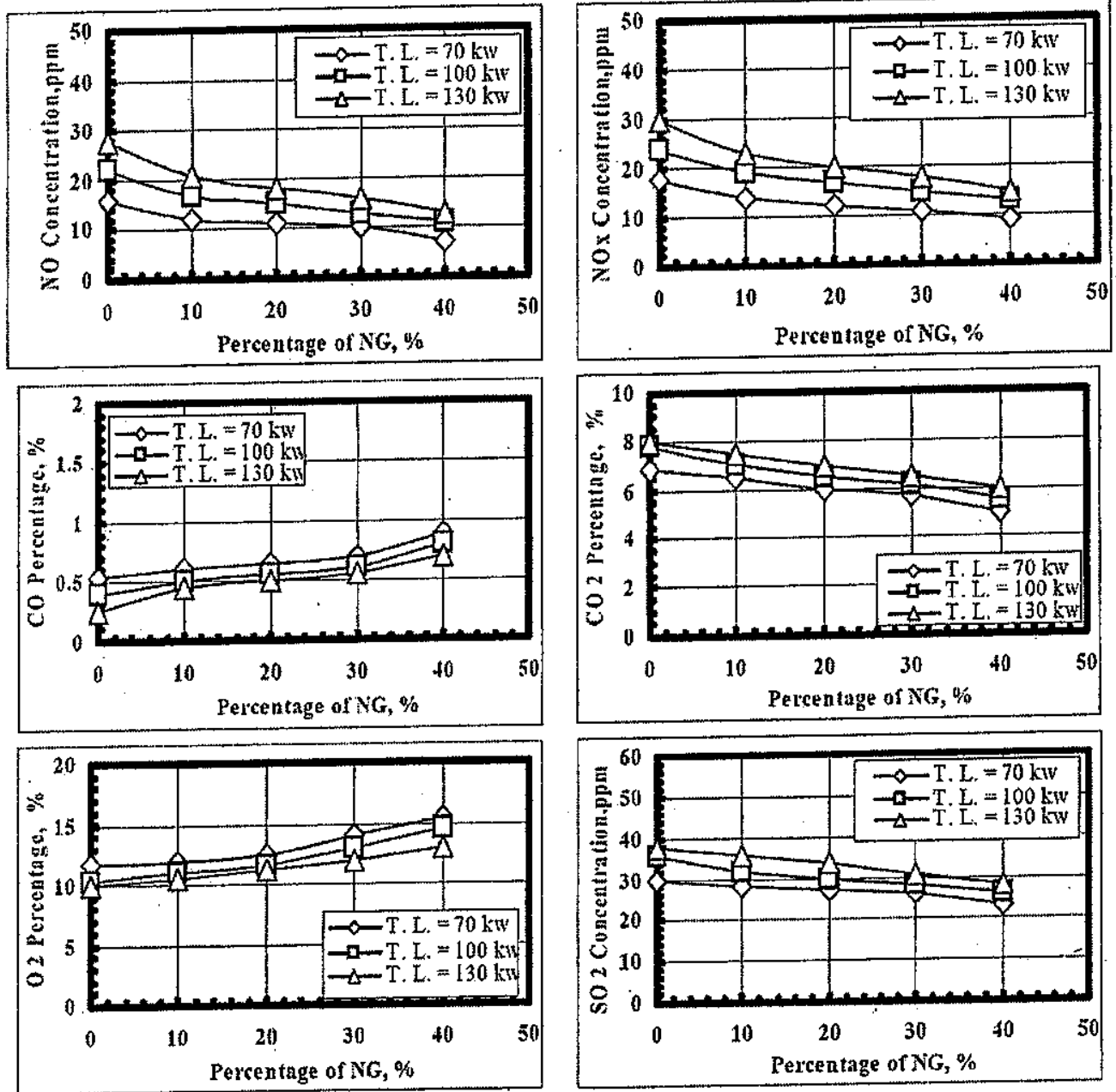

Fig. 13. Effect of adding NG with different percentages on exhaust species concentration.
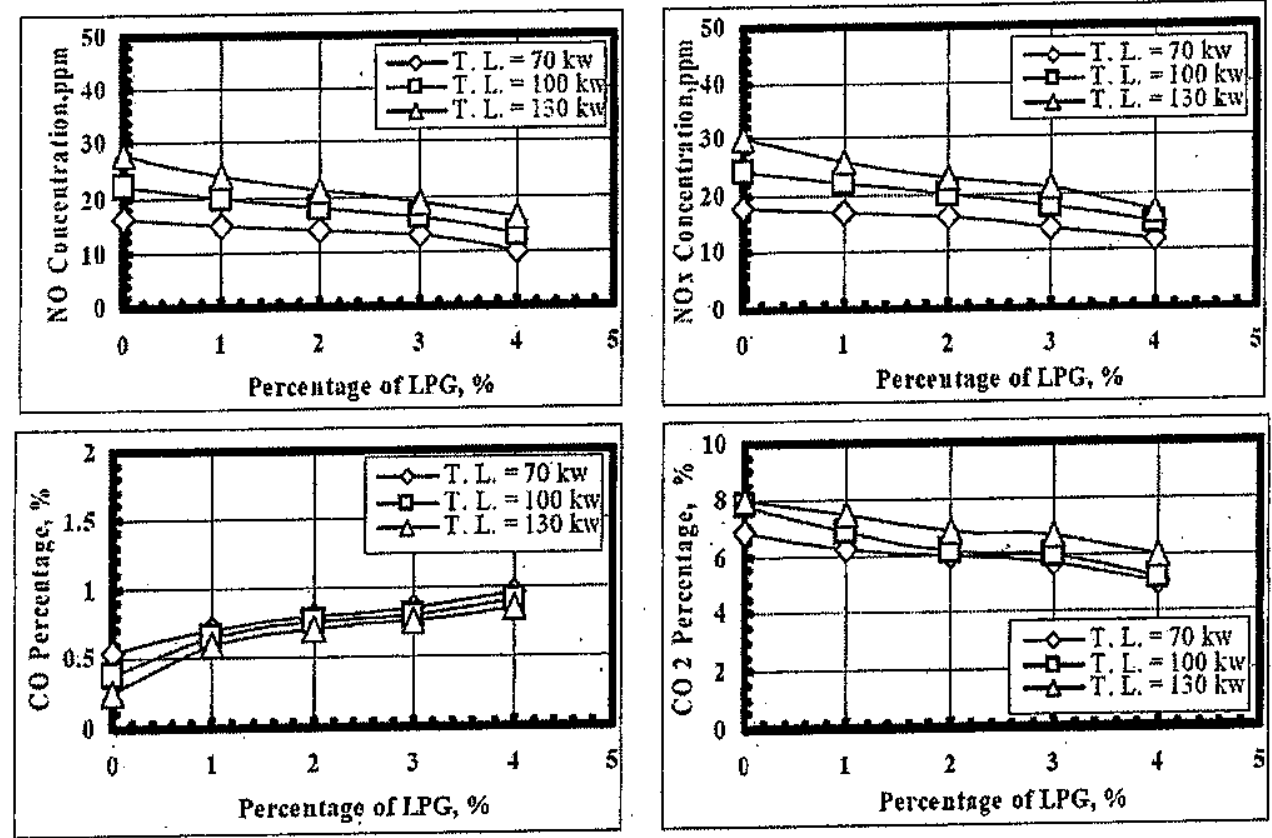

Engineering Research Journal, Minoufiya University, Vol. 32, No. 4, October 2009 

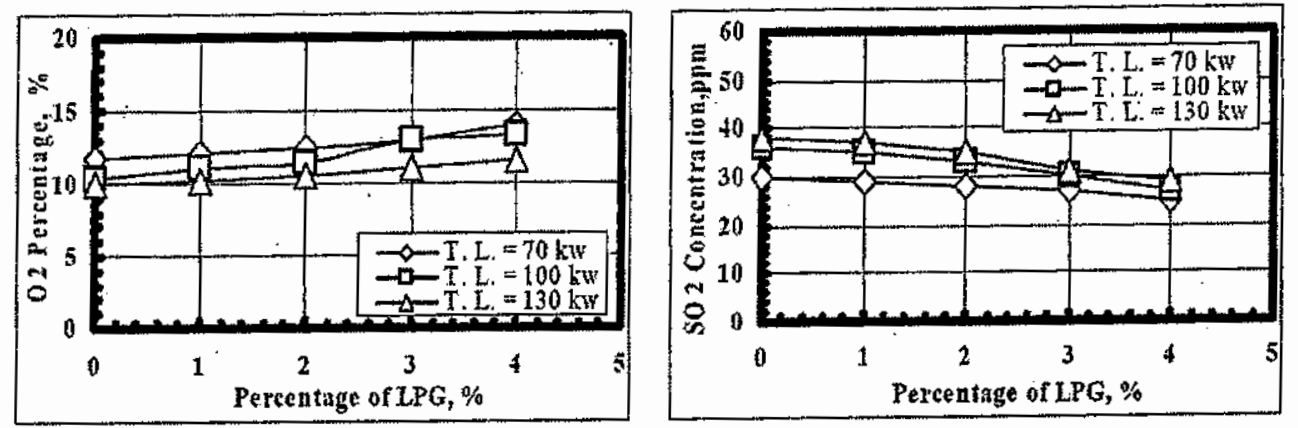

Fig. 14. Effect of adding LPG with different percentages on exhaust species concentrations.
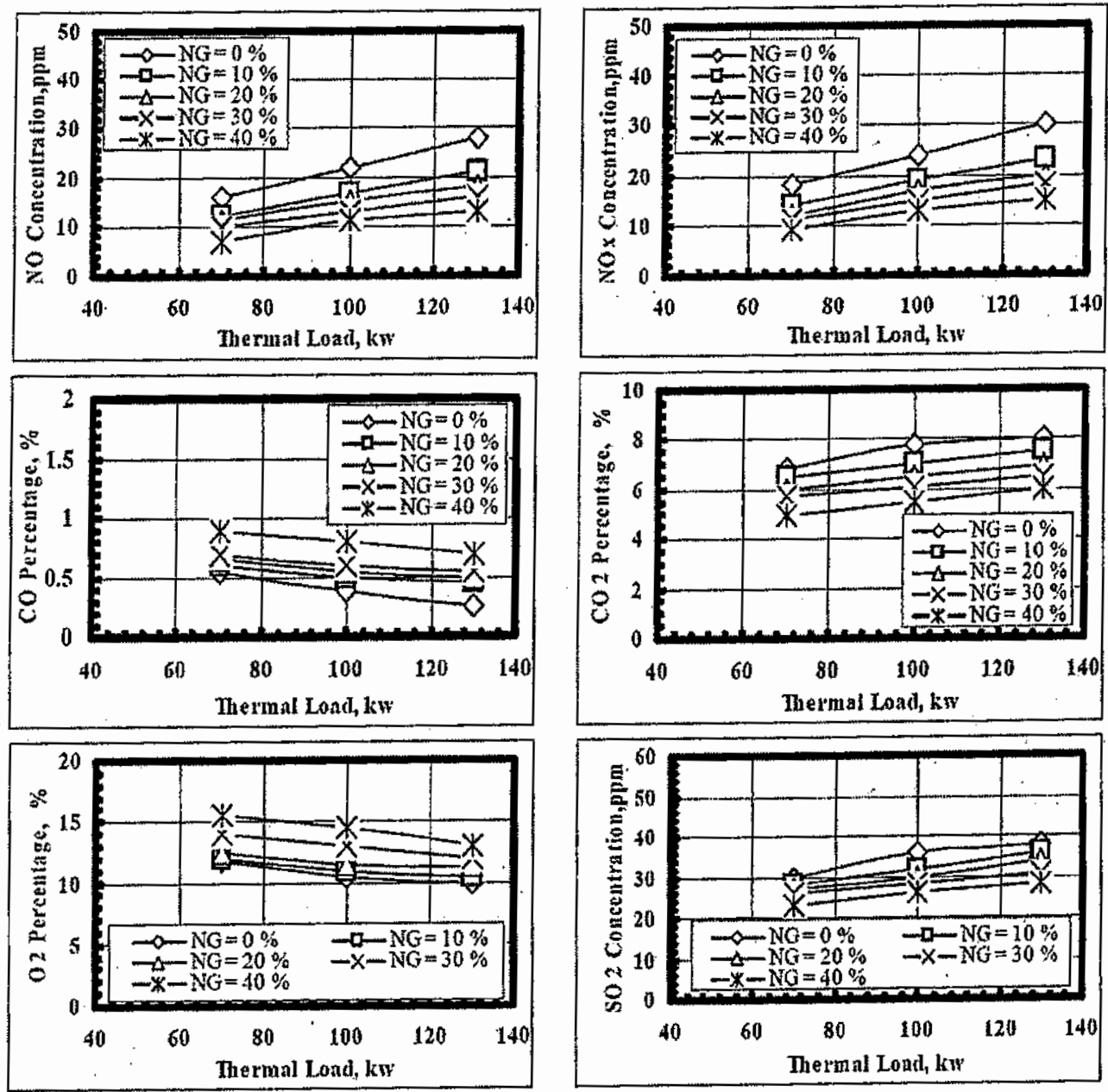

Fig. 15. Effect of changing the input thermal load on exhaust species concentration (when adding NG)
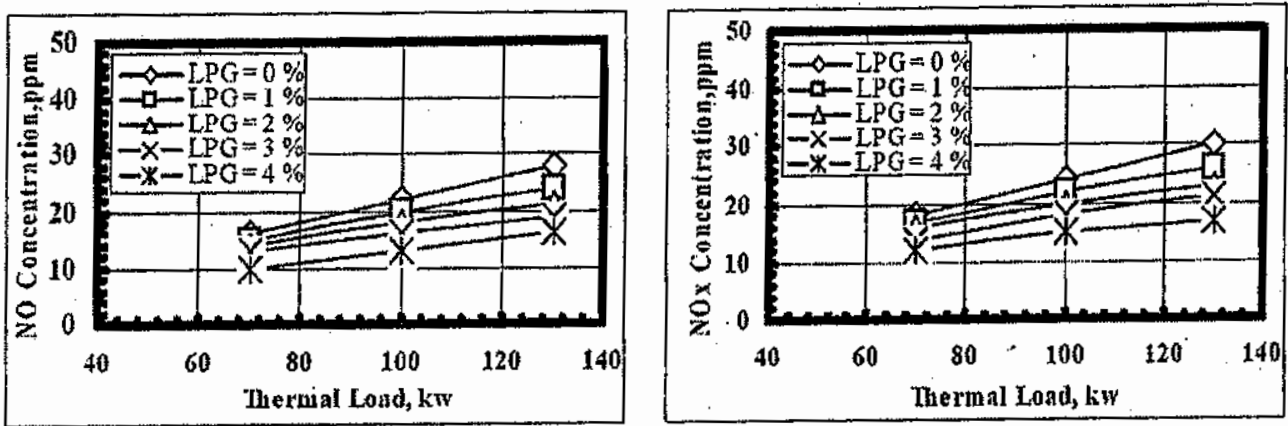

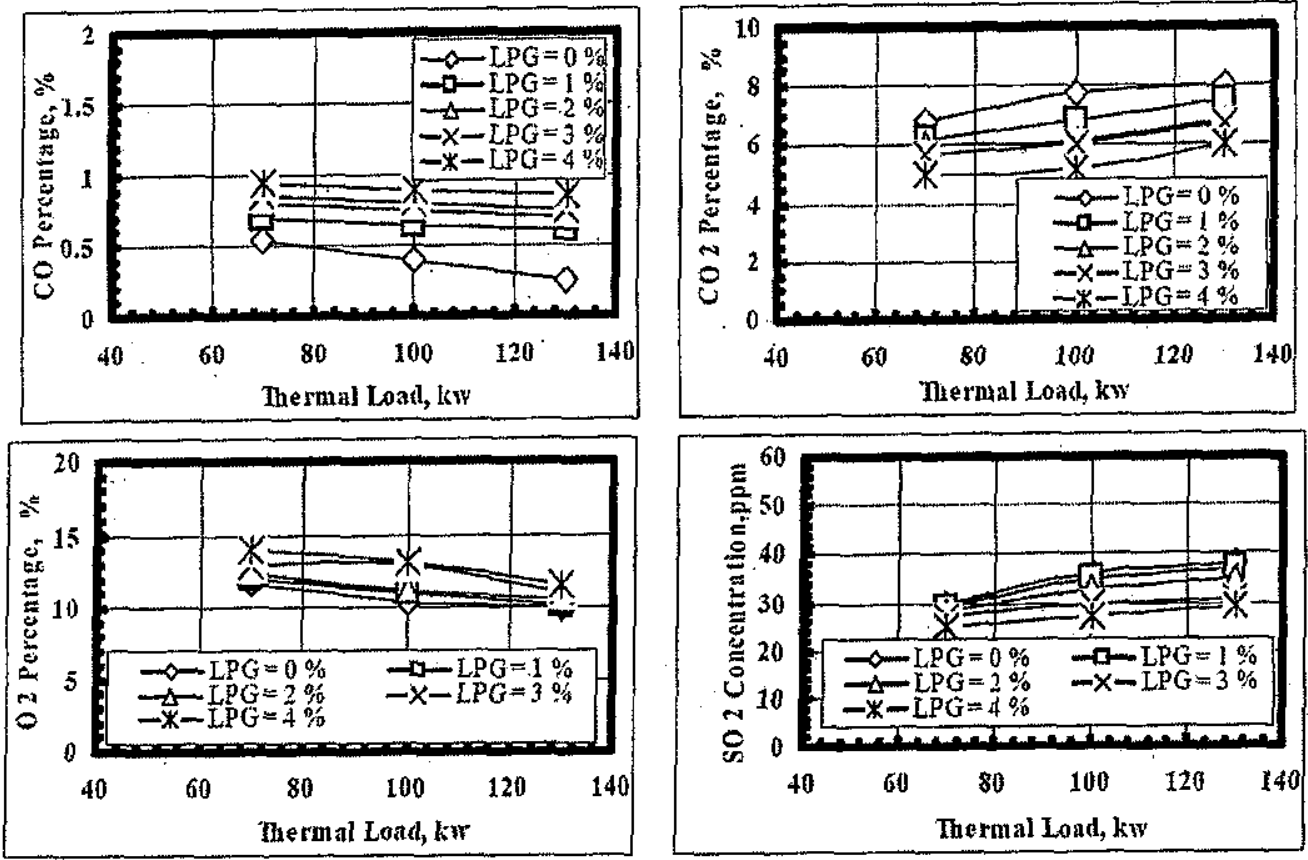

Fig. 16. Effect of changing thermal load on exhaust species concentration (when adding LPG)

Table 3 shows the effects of adding NG and LPG with the same percentage of $4 \%$ at input thermal load of $130 \mathrm{~kW}$, on exhaust species concentration. For NG case, the concentrations of $\mathrm{NO}, \mathrm{NO}_{\mathrm{X}}, \mathrm{CO}_{2}$ and $\mathrm{SO}_{2}$ were lower than that for LPG case: That is because the exhaust gas temperatures of NG were lower than that of $L P G$.

Table 3 Species concentration for NG and LPG at a percentage of $4 \%$

\begin{tabular}{|l|c|c|c|}
\hline \multicolumn{1}{|c|}{ Species } & Kerosene & $\begin{array}{c}\text { Kerosene } \\
\text { and } \\
\text { natural gas }\end{array}$ & $\begin{array}{c}\text { Kerosene } \\
\text { and LPG }\end{array}$ \\
\hline $\mathrm{NO}, \mathrm{ppm}$ & 28 & 13 & 16 \\
\hline $\mathrm{NO}_{\mathrm{x}}, \mathrm{ppm}$ & 30 & 15 & 17 \\
\hline $\mathrm{CO}, \%$ & 0.38 & 0.95 & 0.85 \\
\hline $\mathrm{CO}_{2}, \%$ & 8 & 5.5 & 6 \\
\hline $\mathrm{O}_{2}, \%$ & 10 & 12.5 & 11.5 \\
\hline $\mathrm{SO}_{2}, \mathrm{ppm}$ & 38 & 25 & 29 \\
\hline
\end{tabular}

\section{CONCLUSIONS}

From the present results, the following conclusions are obtained:

1- At air to fuel mass ratio, air swirl number and thermal load of $30,0.5$ and $100 \mathrm{~kW}$, respectively, increasing the percentage of additive NG fuel tends to:

- Shift the high temperature regions upstream,

- Decrease the flame length,

- Decrease $\mathrm{NO}, \mathrm{NO}_{\mathrm{X}}, \mathrm{CO}_{2}$ and $\mathrm{SO}_{2}$ concentrations by about $50,45,29$ and $27 \%$, respectively,
- Increase $\mathrm{CO}$ and $\mathrm{O}_{2}$ concentrations by about 100 and $39 \%$, respectively.

2- At NG percentage, air swirl number and air to fuel mass ratio of $30 \%, 0.50$ and 30 , respectively, increasing the input thermal load tends to:

- Shift the high temperature regions downstream,

- Increases the flame length,

- Increase $\mathrm{NO}, \mathrm{NO}_{\mathrm{X}}, \mathrm{CO}_{2}$ and $\mathrm{SO}_{2}$ concentrations by about $60,63,14$ and $19 \%$, respectively,

- Decrease CO and O2 concentrations by about 21 and $14 \%$, respectively.

3- At air to fuel mass ratio, air swirl number and input thermal load of $30,0.50$ and $100 \mathrm{~kW}$, respectively, increasing the percentage of additive LPG fuel tends to:

-Shift the high temperature regions upstream nearer to the air swirler,

- Decrease the flame length slightly,

- Decrease $\mathrm{NO}, \mathrm{NO}_{\mathrm{X}}, \mathrm{CO}_{2}$ and $\mathrm{SO}_{2}$ concentrations by about $40,37,33$ and $25 \%$, respectively,

- Increase $\mathrm{CO}$ and $\mathrm{O} 2$ concentrations by about 13 and $27 \%$, respectively.

4- At LPG percentage, air swirl number and air to fuel mass ratio of $3 \%, 0.50$ and 30 , respectively, increasing the input thermal load tends to:

- Shift the high temperature regions downstream,

- Increase the flame length,

- Increase $\mathrm{NO}, \mathrm{NO}_{\mathrm{X}}, \mathrm{CO}_{2}$ and $\cdot \mathrm{SO}_{2}$ concentrations by about $46,50,17$ and $15 \%$, respectively,

- Decrease $\mathrm{CO}$ and $\mathrm{O}_{2}$ concentrations by about 12 and $15 \%$, respectively. 
5- For the same additive percentage $4 \%$ of NG and LPG, it was found that NG additive was more effective for the reduction of $\mathrm{NO}$ and $\mathrm{NOx}$ concentrations than those of LPG.

\section{NOMENCLATURE:}

NG Natural Gas

LPG Liquefied Petroleum Gas

\section{REFERENCES}

[1] Abd El-Samed A. K., "Geometrical Effect of a Centrifugal Type Atomizer on Spray Flame Combustion", PSERJ, Vol. 6, No. 1, March (2002).

[2] Arai M., "Flue Gas Recirculation for Low $\mathrm{NO}_{\mathrm{X}}$ Combustion System", Proc. of 2000 International Joint Power Generation Conference, Miami Beach, Florida, Jüly 23-26, (2000).

[3] El-Banhawy Y. H., El-Ehwany A. A. and Hagag E. A., "The Combustion Characteristics of Swirl/Disk-Stabilizes Spray Flames", Proc. $7^{\text {th }}$ conference (Int.) of Mech. Power Eng., Vol.1, II/21-1 21-14, (1990).

[4] El-Mahallawy, F. M. and Habik, S. E., "Fundamental and Technology of Combustion", Elsevier publisher, Amsterdam, Boston, London, New York, Tokyo (2002).

[5] El-Sherif S. A., "Control of Emissions by Gaseous Additives in Methane-Air and Carbon Monoxide-Air Flames", Energy Res. Jour., Vol. 59, pp. 20-36 Oct. (1998).

[6] Farag T. M., "Combustion of Air Blast Atomizer. Sprays in A swirl Type Combustor", PSERJ, Vol. 6, No. 2, pp. 47-64, March (2002).

[7] Farag T. M., "Experimental Study of Natural Gas Diffusion Flame", PSERJ, Vol. 6, No. 2, March (2002).

[8] Farag T. M., Abdel-Mageed S. I., Ibrahim E-S. A. and Abd El-Samed A. K., "Effect of Swirler Size and Rotation on Spray Combustion", PSERJ, Vol. 2, No. 2, September (1998).
[9] Farag T. M., Abdel-Mageed S. I., Ibrahim E-S. A and Abd El-Samed A. K., "Spray Combustion of Dual-Coaxial Swirlers", PSERJ, Vol. 2, No. 2, September (1998).

[10] Farag T. M., Shaaban M. M. and Abdel-Mageed S. I., "Performance Characteristics of Swirl-Type Pressure Atomizer", $7^{\text {th }}$ Int. Conf. of Mech. Power Eng., Cairo, Egypt, December (1990).

[11] Feitelberg A. S., Tangirala V. E., Elliott R. A., Pavri R. E. and Schiefer R. B., "Reduced $\mathrm{NO}_{\mathrm{X}}$ Diffusion Flame Combustors for Industrial Gas Turbines", Journal of Engineering for Gas Turbines and Power, Vol. 123, Oct. (2001).

[12]. Jensen, A. B. and Topsoe, H., "Selective Catalytic Reduction for Maximum $\mathrm{NO}_{\mathrm{X}}$ Emission Control", Scandinavian shipping Gazette, Denmark, (2000).

[13] John, M. P.E., "SCR Design Considerations for $N_{\mathrm{X}}$ Reduction from Gas Turbines", Huntington Environmental Systems, Inc., Houston, Texas, February 13, (2002).

[14] Kleinman M. T., "The health Effects of Air Pollution on Children", PH. D. Thesis, California Univ., September (2000).

[15] Lefebvre A. H., "Gas Turbine Combustion", Hemisphere Publishing Corporation, USA, (1983).

[16] Murugappan S., Acharya S., Gutmark E. J., and Messina T., "Characteristics and Control of Combustion Instabilities in a swirl-stabilized spray Combustor" AIAA / ASME / SAE / ASEE, Joint Propulsion Conference and Exhibit, Los Angeles, CA, June 20-24, (1999).

[17] Syred N., Chigier N. A. and Beer J. M., "Flame Stabilization in Recirculation Zones of Jets With Swirl", $13^{\text {th }}$ Int. Symposium on combustion, (1971).

[18] Taha M. R., "Reducing Emissions Using Dilution Air Mixing With Reactive Rich Mixture", Energy Res. Jour., Vol. 76, pp. 112129 August (2002). 